\title{
THE EXPANDED ROLE OF MONGOLIAN DOMESTIC LIVESTOCK CLASSIFICATION
}

\author{
RUTH I. MESERVE* \\ (Bloomington, Indiana)
}

\begin{abstract}
The observation of nature and attempts to classify it are features of civilisation. The extensive knowledge of domestic livestock possessed by herdsmen on the steppes of Inner Asia helped to form and define various aspects of traditional Mongolian life. Classification charts on the uses of domestic animals, on the five main animals - horses, cattle, camels, sheep and goats - by age, sex, or other breeding characteristics are presented as a foundation. This is then used as a basis for further discussion, also with charts, to examine how this classification system was applied to religion, law, and the social milieu of traditional Mongolia.
\end{abstract}

Key words: Mongolia, domestic animals, classification, religion, law, society.

In a nomadic society one must look to different sources of classification than are traditionally found in sedentary societies where written compendia simplified both the cataloguing of knowledge and access to it, albeit by a literate populace. As might be expected, nomadic steppe society turned to its collective memory - a national "treasury and guardian of all things" [Cicero: De Oratore] - aided in part by the natural surroundings to provide a better understanding and ordering of the world. The historical focus of this essay is on popular identification used in everyday life as opposed to modern scientific classification of animals in general and domestic livestock in particular. This is, therefore, not compatible with Linnaeus' Systema Naturae (1735), nor representative of a variety of other systems developed and debated over the last few centuries such as scala naturae, the "taxonomic tree", "quinary circles", or organ based systems. ${ }^{1}$ Instead, it is the nomadic perception of animals placed in relation to people. Distinctions were often drawn between those animals who served man (domesticated; or wild animals who had performed useful deeds) and those beyond human control (wild, mythic, supernatural).

${ }^{*}$ Ruth I. Meserve, Research Fellow, Department of Central Eurasian Studies, Goodbody Hall 157, Indiana University, 1011 East 3rd Street, Bloomington, IN 47405-7005, USA.

${ }^{1}$ A general discussion of these systems may be found, for example, in Jardine - Secord Spary (1996); Ritvo (1997); and for more general information on dictionaries, encyclopaedias in the 18th and 19th centuries, see Yeo (1991). 
This can lead to certain resemblances to medieval Western Bestiaries, even including the moral precepts. This was especially true in terms of Buddhism, but generally the prevailing view of animals - wild or domesticated - was influenced more by their individual roles in helping or hindering the common man, including historical personages separate from but also sometimes inclusive of tribal legends of origin. Western Bestiaries fit into an almost stylised set list of animals, mainly wild or fabulous, ultimately drawn from the Physiologus of Greek antiquity. The Inner Asian models may be traced back to two major sources. The first is indigenous represented by petroglyphs and the so-called "animal-style" art, which portrayed both wild and domestic animals in an astonishing variety. The second involved books and miniature painting reminiscent of Western Bestiaries, found during the medieval Mamluk and Ilkhanid periods drawing upon earlier Arabic sources ultimately also traceable to Aristotle and the Greek literary tradition. ${ }^{2}$ Much more attuned to the division between the settled and the nomadic, it is not surprising that animals were viewed in different ways by these Inner Asian influenced states.

Unlike Western Bestiaries which were more concerned with the wild and the fabulous or imaginary, Mamluk and Ilkhanid editions of "bestiaries" did include domestic animals (or their wild or feral counterparts) as well as wild animals and fabulous beasts. One "relative novel feature", however, was the "frequent depiction of copulation and related sexual themes." Thus, in al-Jāhiz's Kitāb al-Hayawān (c. 1350) there are scenes of a horse mating with an ass, the mating of goats, of a rooster and hen, or cross breeding between a wolf and a dog. Also depicted are a lion eating the carcass of a cow and dogs eating an ass. In the popular 11th-century bestiary Manāfi 'al-Hayawān (Usefulness of Animals) by the physician Ibn Bukhtāshi' there is a herdsman with animals. ${ }^{4}$ Or in the Ilkhanid editions of Kalila wa Dimna from the Persian translation by Abū al-Maali Nasr Allāh Munshi (12th century) of the mid8th-century version in Arabic by Ibn Maqaffa', there are several miniatures which demonstrate the artist's anatomical knowledge of animals as well as their moods and character. Mostly of wild animals, there are, however, superb depictions of dogs and especially of camels (dromedaries). ${ }^{5}$ Along with the ancient petroglyphs and "animal-style" art, such medieval Inner Asian examples of "bestiaries" and animal lore included domesticated animals along with the wild and fabulous.

Although all Altaic languages would permit an alphabetical system of classification, this was not common. Instead categories were used, at first because they were easy to remember, but even later they were also adopted for written materials. This is probably due also in part because of influence from both the Indian tradition and from Chinese categorical thought. ${ }^{6}$ Use of the senses was of particular importance.

${ }^{2}$ For example, see Hillenbrand (1990) and Cowen (1989).

${ }^{3}$ Hillenbrand (1990), p. 155. For cross breeding and mating see Figures 23 (p. 177), 26 (p. 178), 27 (p. 179), 29 (p. 180). For material and illustrations on the consuming of carcasses see Figures 18 (p. 174), 25 (p. 178).

${ }^{4}$ Hillenbrand (1990), Figure 38, p. 184.

${ }^{5}$ See Cowen (1989) for a detailed discussion.

${ }^{6}$ For a thorough discussion of the Indian tradition, see Smith (1994), especially the chapter on "Classifying Fauna", pp. 241-286. The article by Bodde (1939) treats, for example, correlative 
Often such classifying tools took a visual form, particularly in terms of colours, shadings, and marking patterns. Also useful were touch (in terms of defining land features and soils) and taste (especially in terms of water). ${ }^{7}$ Acutely aware of sound, hunting practices employed a wide range of calls in imitation of wildlife or in distinguishing domestic animals. Weather conditions were highly classified to enumerate temperatures, winds, ice, snow and how these affected everyday life. Time could be expressed in terms of animal life, both wild and domesticated, beyond the expected differences due to seasonal migration patterns, between the diurnal and nocturnal, or the twelve-year animal cycle popular in calendrical measurement. ${ }^{8}$

It is my intention in this paper, to examine how livestock classification was used to catalogue knowledge and, thus, played a role in nomadic steppe society. I have limited my discussion to Mongolian livestock classification examples, though one could certainly do the same for the remainder of the Altaic-speaking world. For further development of this topic, I have also indicated comparative studies by scholars on classification. For clarity and brevity much of this material is presented in the form of charts, which should be viewed as examples and not as a list of every possible term. I have not included in this discussion examples of domestic livestock terms used to classify other plants or animals, ${ }^{9}$ because the main concern here will be the special role livestock plays in direct relation to various human activities.

Many of the Central Eurasian steppe peoples (including pre-Islamic Central Asians) considered the natural world in very special and prominent ways in both the religious and secular life of the community. No doubt this was reinforced by shamanism, animism, and various forms of Buddhism. Chart 1 draws one's attention to this animal world ${ }^{10}$ and begins to narrow the focus from wild animals ${ }^{11}$ to domestic animals and especially to quadruped mammals, which may then lead into a more detailed discussion of domestic livestock.

This general description of animals could be greatly refined adding categories for birds, reptiles or fishes, but the focus here is directed toward a further refining of the classification of domestic livestock common to Mongolian steppe herdsmen (kegere-yin irgen) and the expanded role these animals played in the everyday life of Mongolian society. Before looking at individual animals, I would like to present some of the ways of looking at domestic livestock as a group: by number, use, location, ${ }^{12}$ sex or reproductive status, colour, ${ }^{13}$ gait or movement, and

and cosmological thought in Chinese categorical thinking, both of which were also important to Inner Asian nomadic classification. For the ancient Persian tradition, see Schmidt (1980).

${ }_{7}^{7}$ An excellent example of this may be found in a geomancy text studied by Sárközi (1976).

${ }^{8}$ Lubsangjab ((1974) discusses such applications to time.

${ }^{9}$ Examples of this type of classification may be found, for example, in Bawden (1988) or Hasbagan - Chen (1996).

${ }^{10}$ For a general comparative study of Turkic and Mongolian terms see Pelliot (1931).

${ }^{11}$ Wild animals have also been dealt with by Poppe (1964).

${ }^{12}$ Location as an identifying feature is commonly applied to various breeds of sheep; see for example Batsukh - Zagdsuren (1991). This may also be applied to cattle in China - see Qiu Ju - Chang (1993) - but is, perhaps, more a Chinese phenomenon.

${ }^{13}$ Some important work has been done on classification of livestock by colour in Altaic languages by Cirtautas (1965), Poppe (1977), Uray-Kőhalmi (1966), to mention a few. It is also 


\section{A Generic Classification for Animals ${ }^{14}$}

\begin{tabular}{|c|c|}
\hline \multicolumn{2}{|c|}{ LIVING BEINGS = amitan } \\
\hline \multicolumn{2}{|c|}{ 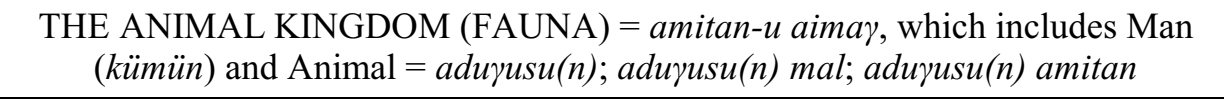 } \\
\hline 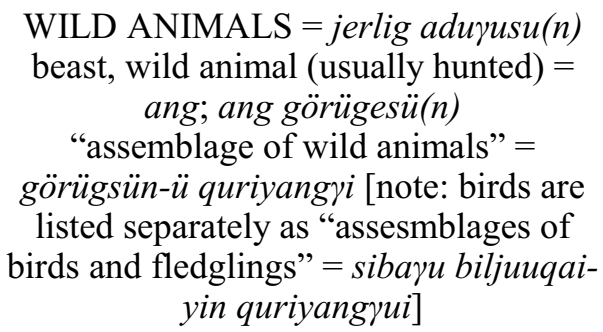 & $\begin{array}{c}\text { DOMESTIC ANIMALS = mal } \\
\text { livestock = adurun mal; sürüg mal } \\
\text { (domestic animals, collectively); adal } \\
\text { mal; adal ed mal } \\
\text { male }(\hat{\jmath})-\text { er-e; eregcin } \\
\text { female }(+)-\text { em-e; emegcin }\end{array}$ \\
\hline \multicolumn{2}{|c|}{$\begin{array}{l}\text { MAMMALS, milk-producing animals = sün-iyer amidura-qu amitan } \\
\text { Milk-producing domestic livestock }= \\
\text { sayali, sayali-yin mal }\end{array}$} \\
\hline $\begin{array}{l}\text { wild animal: CARNIVORES, beasts of } \\
\text { prey = ariyatan [=arayatan] } \\
\text { o - gendün } \\
\text { o - ölügcin, gicige } \\
\text { wild animal: HERBIVORES }= \\
\text { görügesü }(n)\end{array}$ & 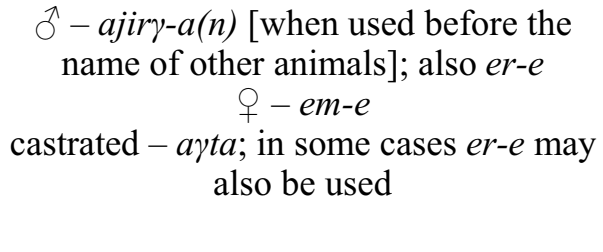 \\
\hline \multicolumn{2}{|c|}{ 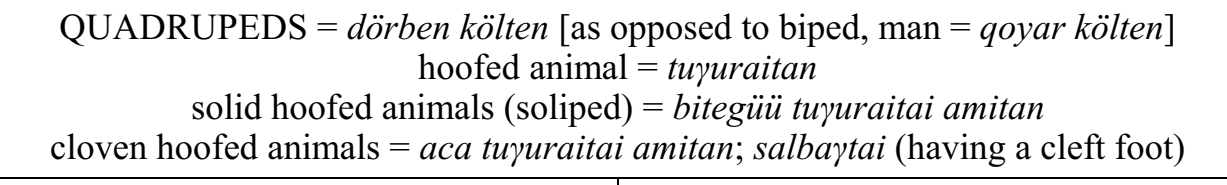 } \\
\hline & 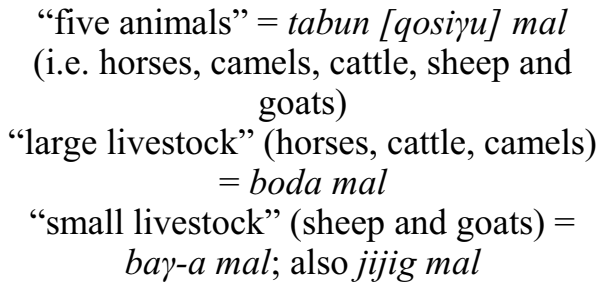 \\
\hline
\end{tabular}

age. ${ }^{15}$ There is even an entire range of cries made by domestic livestock which distin-

readily apparent that colour remains important to this day when examining such volumes as Amguleng (1990) with the extensive range of colour and marking used to distinguish horses and cattle among the Mongolian populations of China.

${ }^{14}$ Extremely useful in terms of classification are the large, relatively late, multi-language dictionaries such as the Wu-t'i Ch'ing-wen chien; for the Mongolian see Krueger (1963).

${ }^{15}$ Especially important work on this was begun by K. Uray-Köhalmi (1959), but it is often overlooked. In many respects I hope to add to her original project, expanding it beyond determina- 
guishes not only different species, but also male, female, and castrated animals within a single species. ${ }^{16}$

2. Classification of Livestock

"Assemblage of animal husbandry" = mal tejigebüri-yin quriyangyui

\begin{tabular}{|c|c|}
\hline CATEGORY & EXAMPLES \\
\hline by number & 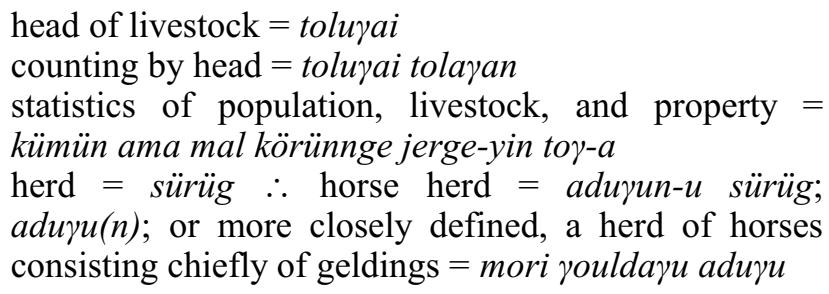 \\
\hline by use (or lack of use) & 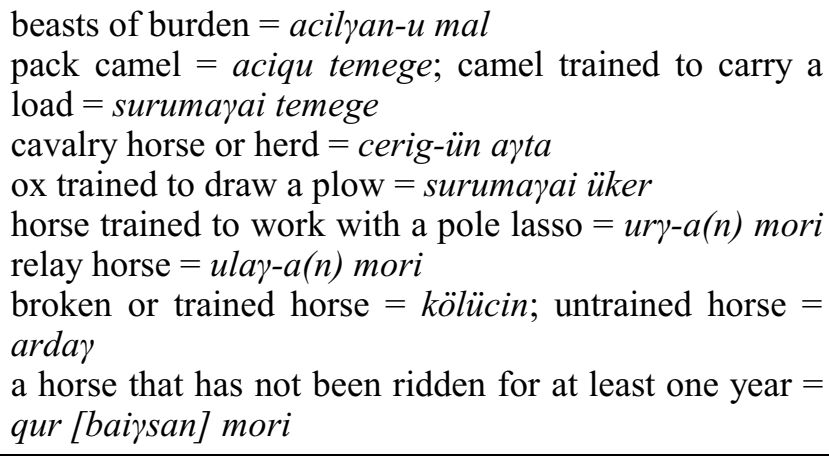 \\
\hline by location & $\begin{array}{l}\text { domestic livestock kept at hand within easy reach, e.g. } \\
\text { sheep, goats, cattle = yar mal } \\
\text { lost or stray livestock = aldayul mal } \\
\text { stray animals (livestock or dogs) }=\text { jolbin } \sim \text { zolbin } \\
\text { (Oirat) } \\
\text { livestock driven onto the steppe }=\text { ilden mal } / \text { elden mal } \\
\text { ownerless livestock }=\text { ejen ügei mal } \\
\text { horse of the steppe }=\text { keger-e-yin mori } \\
\text { horse kept separately as a reserve }=\text { ongquu(n) morin } \\
\text { livestock of a lamasery = jasyn mal }(\text { Khalkha) }\end{array}$ \\
\hline by condition or quality & $\begin{array}{l}\text { thoroughbred = sain uүsayan-u mal } \\
\text { worn out horse = adasq-a mori } \\
\text { a mediocre horse = anai mori } \\
\text { a poor or slow horse = bolki mori }\end{array}$ \\
\hline
\end{tabular}

(continued on next page)

tion of age thus establishing the function of classification in nomadic society. At the same time, I am immensely grateful for her early study.

${ }^{16}$ For examples of this, see Coloo (1976), pp. 64-65. 


\begin{tabular}{|c|c|}
\hline CATEGORY & EXAMPLES \\
\hline $\begin{array}{l}\text { by sex or reproductive } \\
\text { status (see also charts for } \\
\text { individual animals) }\end{array}$ & 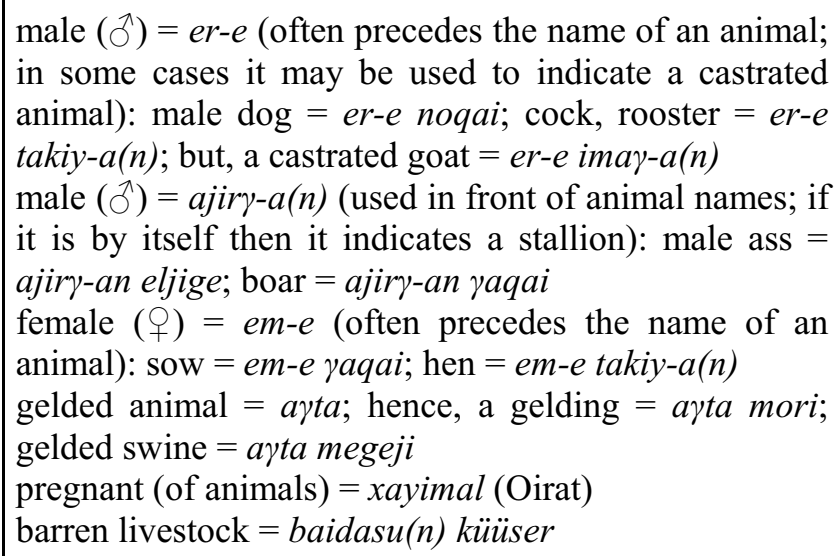 \\
\hline by colour & 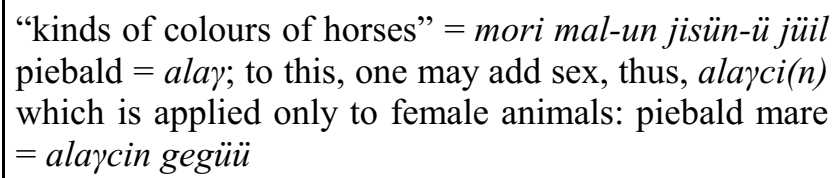 \\
\hline by gait (horses) & 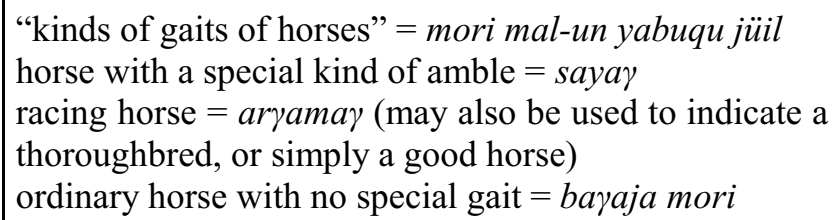 \\
\hline $\begin{array}{l}\text { by age: by number or by } \\
\text { condition of teeth [Note: } \\
\text { this classification by con- } \\
\text { dition of the teeth is } \\
\text { found more among the } \\
\text { Khalkha Mongols than } \\
\text { among the west Mongols/ } \\
\text { Oirats/Kalmyks] } \\
\text { (see also charts for indi- } \\
\text { vidual animals) }\end{array}$ & $\begin{array}{l}\text { newborn animals = töl mal } \\
\text { young domestic animals }=\text { tejiyebüri amitan (when } \\
\text { used with ger "tent" it can mean animals other than the } \\
\text { traditional five domestic animals) } \\
\text { 2-year-old livestock = xoyimusutai (Oirat); also sarva } \\
\text { (Oirat) } \\
5 \text {-year-old livestock = tuulan, tuulun (Oirat); 5-year- } \\
\text { old female livestock = tuuljin, tuljin (Oirat) } \\
6 \text { years old (full set of teeth) = güyiceleng } \\
7-8 \text { years old (worn on the } 4 \text { edges of the teeth) }= \\
\text { dörben jiq-a } \\
8-9 \text { years old (worn below the edges) }=\text { dour-a jiq- } a \\
10-11 \text { years old (wear over entire set of teeth) = deger- } \\
\text { e bürin } \\
11-12 \text { years old (completely worn) = narin bürin } \\
\text { above } 12 \text { years old (teeth are like bone; "Knochen- } \\
\text { zahn") =yasun sidü } \\
\text { old (of both man and animal) = kögsin }\end{array}$ \\
\hline
\end{tabular}


While the above two charts begin to delineate how the Mongol herdsman thought of animals in general and livestock in particular, to gain a clear understanding of the role of classification of domestic animals in Mongolian society, it is necessary to look at the "five traditional animals" tabun [qosizu] mal - i.e. horses, cattle, camels, sheep and goats - in greater detail. ${ }^{17}$ Some list the "five animals" in the hierarchic order given in the previous sentence. ${ }^{18}$ While I have followed this order in the presentation that follows, it should be pointed out that it is often not listed this way, especially in modern bilingual dictionaries. In historical times, when one was forced to consider the value of the animals, certainly 1 camel was always worth more than 1 horse. The rate of 1 boda $\sim \operatorname{bodu}$ (i.e. a unit of large livestock) equalled 1 horse, $1 \mathrm{cow}$, or 1 bull; but 1 camel was equal to $1 \frac{1 / 2-2}{b o d a}$. For example, the Abakan Inscription (c. 17th century) on the bank of the Yenisei River is considered to be a yarliq which dealt with the capture of enemies, their execution and burial, including the slaughter and interring of mares and the planting of flowers on the graves. The order specified, however, that barren she-camels should be spared and seized by the bridle, for "they may be destined to become mothers". ${ }^{19}$ Clearly in terms of value alone, a camel exceeded that of mares to the extent that it would be protected even if there was only a remote chance that it could successfully breed.

Yet, when qualifications beyond value were taken into consideration, first among the traditional "five animals" was the horse. It played a key role in the economy, military, and social life of the community. Although Mongolians certainly used colour to distinguish animals, such classification was not out of proportion to other concerns, such as age, sex, reproductive abilities, or prime breeding grounds. During the Ch'ing dynasty (1644-1911), when the Manchu imperial horse pastures were tended by Mongolians, the herdsmen were divided into "breeders of white, piebald, bay, chestnut, black, white-nosed, and star-faced horses. When they [the Manchus] desired horses they sent up for a certain number, all of one colour. Indeed, colour was their sole concern... The Mongols felt that since the Manchus lacked understanding of the good points of a horse it was folly ever to send a superior animal down to China." 20 This attitude had been common throughout the history of Inner Asian relations with China. Horses traded at the border markets were usually inferior; good animals were sent North. This was not only an economic ploy but also a strategic advantage. There was little point in trading the best horses to a potential enemy. As such the Mongols did recognise horses bred in different regions.

Extensive true cattle production (as opposed to yak or hainag breeding), especially in the Inner Mongolian Autonomous Region of China, has increased interest and value in this animal. The classification of cattle could take on weather related

${ }^{17}$ Bosson (1993) argues the need for a more careful and detailed definition of the five traditional animals and the terminology associated with these animals.

${ }^{18}$ Jagchid - Hyer (1979), p. 14

${ }^{19}$ Riasanovsky (1965), p. 54. Badly damaged over the centuries and difficult to read as reported by Riasanovsky, this inscription is not in the extremely useful list provided by Weiers (1969), pp. 203-224, and has not received renewed interest or attention.

${ }^{20}$ Larson (1930), p. 165. 
3. Classification of Horses $(\operatorname{mori}[n])^{21}$

\begin{tabular}{|c|c|c|c|}
\hline MALE (ð) & FEMALE ( $(+)$ & NEUTER & WILD \\
\hline $\begin{array}{l}\text { stallion }=\text { ajir } \gamma- \\
a(n)\end{array}$ & 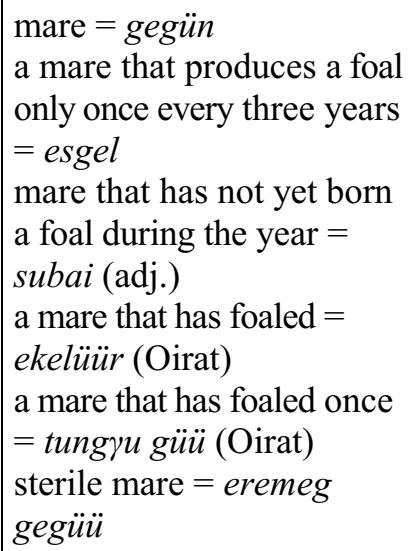 & $\begin{array}{l}\text { gelding }=a \gamma t a \\
\text { ayta mori }\end{array}$ & $\begin{array}{l}\text { wild horse }= \\
\text { taki }\end{array}$ \\
\hline \multicolumn{4}{|c|}{ CLASSIFICATION BY AGE } \\
\hline $0-1$ year & \multicolumn{3}{|c|}{ foal up to 1 year old; yearling $=u n a \gamma-a(n)$} \\
\hline $1-2$ years & \multicolumn{3}{|c|}{ colt between 1 and 2 years old $=d a \gamma a \gamma-a(n)$} \\
\hline 2 years old & \multicolumn{3}{|c|}{$\begin{array}{l}\text { 2-year-old horse }=\text { dayatai } \text { (historical: Altan tobci); sarbā, } \\
\text { sarbāi, sarva (Oirat) }\end{array}$} \\
\hline 3 years old & \multicolumn{3}{|c|}{$\begin{array}{l}\text { 3-year-old stallion = sidüleng üriy-e; } \text {, runan } \\
\text { 3-year-old mare = yunaji(n) gegüü; beyisen, beyisün (Oirat) }\end{array}$} \\
\hline $3-4$ years & \multicolumn{3}{|c|}{ 3-4-year-old mare that has not yet had a foal = baidasu(n) } \\
\hline $3-5$ years & \multicolumn{3}{|c|}{$3-5$ year-old stallion $=$ üriy-e $[=$ ürege $]$} \\
\hline 4 years old & \multicolumn{3}{|c|}{ 4-year-old stallion $=$ kijaralang üriy-e } \\
\hline 5 years old & \multicolumn{3}{|c|}{$\begin{array}{l}\text { 5-year-old horse }=\text { soyuralang } \\
5 \text {-year-old stallion }=\text { soyuralang üriy-e }\end{array}$} \\
\hline 6 years old & \multicolumn{3}{|c|}{ 6-year-old horse $=$ qabci soyuyalang } \\
\hline
\end{tabular}

${ }^{21}$ A good deal of work has been done on horses. A recent "dictionary" of the horse has been compiled by Jambaldorj (1996). For distinguishing various types of horses in present day China with terminology in Mongolian, Chinese and English, see Amguleng (1990); for Mongolian terminology see Poppe (1962); for comparative studies see Sinor (1965) and Mayrhofer (1960). For classification by region see Larson (1930), pp. 166-170. 


\begin{tabular}{|l|l|}
\hline \multicolumn{2}{|c|}{ CLASSIFICATION BY REGION } \\
\hline Gobi horses & $\begin{array}{l}\text { shorter in height; mature slowly; teeth wear faster } \\
\text { due to sand in grass; good endurance }\end{array}$ \\
\hline e Mongolia (i.e. east of Gobi) & good pacing horses; speed \\
\hline ne Mongolia: Kerulen Valley & $\begin{array}{l}\text { most favourable region for horses; larger and } \\
\text { stronger horses }\end{array}$ \\
\hline nw Mongolia & $\begin{array}{l}\text { horses under-sized, usually below 12 hands; under- } \\
\text { developed due to short grazing season; higher mor- } \\
\text { tality rates; those animals that survive are very sturdy }\end{array}$ \\
\hline Altai-Ili district & larger animals but not as speedy; good appearance \\
\hline sw Mongolia: Ordos & smaller animals; undeveloped in appearance \\
\hline
\end{tabular}

phenomena in folk sayings. To express the bitter cold, for example, one could say that it was cold enough to crack or break the horns of a three-year-old bull (gunyn ever xugaram gurvan yesnii xüiten [Khalkha]). ${ }^{22}$

Camel raising areas were also recognised. Historically, those bred by the Khalkha Mongols were considered best and distinguishable from smaller and more delicate camels bred in the Alashan region that had darker hair or in Kokonur that were shorter in stature with a somewhat truncated muzzle. Also like horses, camels were used to calculate the distance of a journey: the average day for a pack camel covering 45 kilometres or for a horse, $70-80$ kilometres. $^{23}$

A mobile museum devoted to the camel as well as a "dictionary" of the camel have recently appeared in Mongolia in an attempt to preserve the cultural heritage of this animal.

Sheep were also distinguished by the location of various breeds, by fleece quality for making wool or by quality of meat for human consumption. ${ }^{25}$

${ }^{22}$ Bawden (1997), p. 101. In another weather related example, for a horse "to go at an amble", the verb joroolox is used in Khalkha, but it may also be used in the figurative sense of "snow flurries" (Bawden 1997, p. 160). For Turkic examples of similar sayings on horses, dogs, asses, camels, sheep, goats, wolves, and pigs, see Yüce (1991).

${ }^{23}$ See Howorth (1927), IV, p. 64 for breeding areas and p. 86 for journey measurement.

${ }^{24}$ See Jambaldorj (1997).

${ }^{25}$ For Mongolia, the study by Batsukh and Zagdsuren (1991) is especially important for details of the various sheep breeding regions and the characteristics of the animals. A similar, but much earlier study, was carried out for Inner Mongolia by the Australian researcher I. Clunies Ross in 1936; his study also included Manchukuo, Korea and Japan (Ross 1936). I would like to thank Prof. Igor de Rachewiltz who helped me to obtain a copy of this report. 
4. Classification of Cattle (üker), including Yaks (sarluү), Water Buffalo (üker usun), and Hybrids (e.g. Hainag = qainuү): "Kinds of cattle" = üker-ün jüil ${ }^{26}$

\begin{tabular}{|c|c|c|c|}
\hline $\operatorname{MALE}(\widehat{\jmath})$ & FEMALE $(q)$ & NEUTER & WILD \\
\hline bull $=b u q-a$ & $\begin{array}{l}\text { cow = üniy-e }(n) \\
\text { milk cow = sün-ü mal; sadaq, } \\
\text { sayili (Oirat) } \\
\text { a cow whose calf has been weaned } \\
\text { or has died = qaiday üniy-e } \\
\text { a cow expected to calve during the } \\
\text { year but did not = subai üniy-e } \\
\text { barren or sterile cow = eremeg } \\
\text { üniy-e, qusurung üniy-e } \\
\text { a cow that is barren every other } \\
\text { year = önjilgen qusurung }\end{array}$ & $\mathrm{ox}=\check{s} a r$ & $\begin{array}{l}\text { wild bull } \\
\text { (bison)= } \\
\text { buq-a } \\
\text { görügesün } \\
\text { wild yak } \\
\text { (buffalo)= } \\
u d u\end{array}$ \\
\hline \multicolumn{4}{|c|}{ BY BREEDING } \\
\hline \multicolumn{4}{|c|}{ 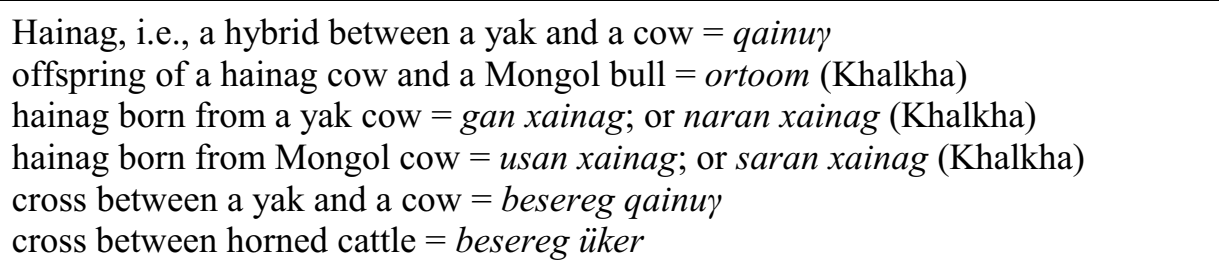 } \\
\hline \multicolumn{4}{|c|}{ BY AGE } \\
\hline $0-1$ year & \multicolumn{3}{|l|}{ calf less than 1 year old $=$ turul } \\
\hline $1-2$ years & \multicolumn{3}{|l|}{ 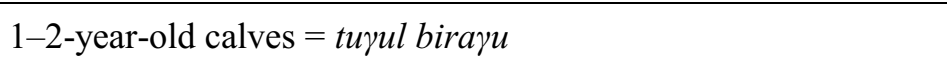 } \\
\hline 2 years & \multicolumn{3}{|l|}{ calf in its 2 nd year $=\operatorname{bira\gamma u}(n)$} \\
\hline 3 years & \multicolumn{3}{|c|}{ 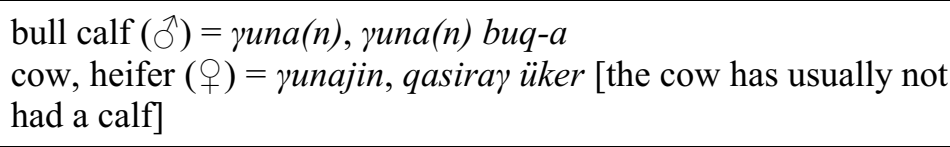 } \\
\hline 4 years & \multicolumn{3}{|c|}{$\begin{array}{l}\text { bull }(ð)=\text { dön-e }(n) \\
\text { cow }(+)=\text { döneji }(n) \\
\text { castrated bull } 4 \text { years old or more }=\text { er-e šar } \ddot{\text { inker }}\end{array}$} \\
\hline 5 years & \multicolumn{3}{|l|}{ 5-year-old ox = soyurulang } \\
\hline
\end{tabular}

${ }^{26}$ For studies on cattle see Amguleng (1990); Bazin (1970/1994); Qiu-Ju-Chang (1993); Sinor (1962). 
5. Classification of Camels $[\text { temege }(n)]^{27}$

\begin{tabular}{|c|c|c|c|c|}
\hline \multicolumn{2}{|c|}{$\operatorname{MALE}\left(ठ^{\Uparrow}\right)$} & FEMALE $(+)$ & NEUTER & WILD \\
\hline \multicolumn{2}{|c|}{ 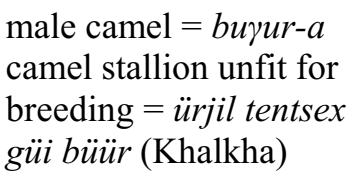 } & $\begin{array}{l}\text { female camel = } \\
\text { ingge }(n), \\
\text { ingge }(n) \text { temege }\end{array}$ & $\begin{array}{l}\text { castrated camel = } \\
\operatorname{ata}(n), \operatorname{ata}(n) \\
\text { temege }\end{array}$ & $\begin{array}{l}\text { wild camel = } \\
\text { temegen } \\
\text { görügesü }\end{array}$ \\
\hline \multicolumn{5}{|c|}{ BY HUMPS } \\
\hline $\begin{array}{l}1 \text { hump } \\
2 \text { humps }\end{array}$ & \multicolumn{4}{|c|}{$\begin{array}{l}\text { dromedary = yanca bökütei; nige bökütei temege; mai temē, maya } \\
\text { teme (Oirat) } \\
\text { Bactrian camel = qoyar bökütei temege }\end{array}$} \\
\hline \multicolumn{5}{|c|}{ BY AGE } \\
\hline 1 year & \multicolumn{4}{|c|}{ young camel in its first year $=$ botu $a(n)$} \\
\hline 2 years & \multicolumn{4}{|c|}{ young camel in its second year $=$ torum } \\
\hline $3-5$ years & \multicolumn{4}{|c|}{ 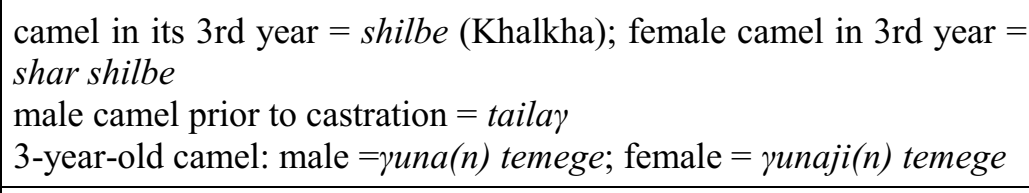 } \\
\hline 4 years & \multicolumn{4}{|c|}{$\begin{array}{l}\text { 4-year-old male camel }=\text { dön-e }(n) \\
\text { 4-year-old female camel }=\text { döneji }(n)\end{array}$} \\
\hline
\end{tabular}

6. Classification of Sheep [qoni(n)] and Goats [imay-a(n)]

"Small animals" (collective for sheep and goats): bay-a mal ${ }^{28}$

\begin{tabular}{|c|c|c|c|}
\hline MALE $\left(\delta^{\lambda}\right)$ & FEMALE $(q)$ & NEUTER & WILD \\
\hline $\begin{array}{l}\text { male goat, buck } \\
=u q u n-a, \\
\text { babana }-a \\
\text { ram, uncastrated } \\
\text { lamb = quca(n) }\end{array}$ & $\begin{array}{l}\text { she-goat, ewe = } \\
\text { em-e ima }-a(n) \\
\text { ewe (sheep) }= \\
\text { em-e qoni }(n)\end{array}$ & $\begin{array}{l}\text { castrated goat, ram }=e r-e \\
i m a \gamma-a(n) \\
\text { castrated ram, wether }=\text { irge } \\
\text { castrated goat }=\text { serke } \\
\text { castrated ram }=\text { er-e qoni }(n)\end{array}$ & 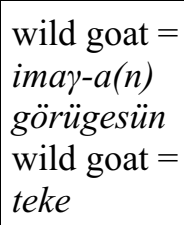 \\
\hline
\end{tabular}

(continued on next page)

${ }^{27}$ The classification of camels by age using dentition extends over a much longer number of years than for the horse. For information and collared illustrations of tooth wear on camels see Ishnyam - Maidar (1988), pp. 103-112. $(1967 / 1994)$

${ }^{28}$ For additional information on sheep and goats see Batsukh - Zagdsuren (1991); Bazin 


\begin{tabular}{|c|c|}
\hline \multicolumn{2}{|r|}{ BY AGE } \\
\hline general & young of sheep and goats, often weak or sick $=d u d u r a i$ \\
\hline under 1 year & $\begin{array}{l}\text { under 7-day-old lamb = nyalx }(\text { or baga }) \text { xörve }(\text { Khalkha }) \\
\text { 7-20-day-old lamb }=\text { dund xörve }(\text { Khalkha }) \\
\text { over } 20 \text {-day-old lamb = ix xörve }(\text { Khalkha })\end{array}$ \\
\hline 1 year & 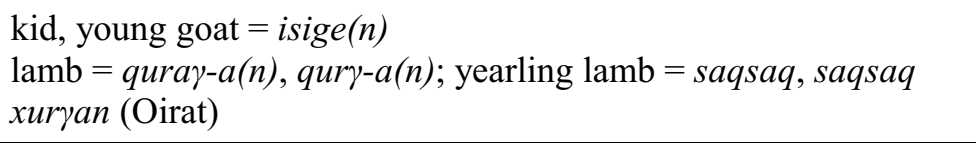 \\
\hline 2 years & $\begin{array}{l}\text { last year's lamb, hence } 2 \text { years old }=\text { tölüge }(n) \\
\text { 2-year-old sheep }=\text { sidüleng } \\
\text { 2-year-old goat }=\text { siyineq }(\text { Oirat })\end{array}$ \\
\hline $2-3$ years & ewes $(+)$ between 2 and 3 years with young for the 1 st time $=j u s a \gamma$ \\
\hline 3 years & 3-year-old sheep = silüge, soyuralang \\
\hline 4 years & 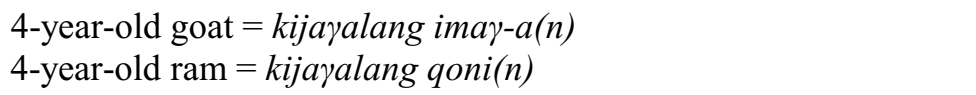 \\
\hline
\end{tabular}

7. Classification of Domestic Animals Other than the "Traditional Five":

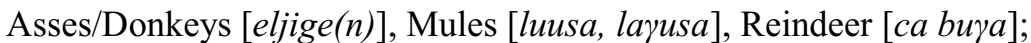

Pigs [raqai], Chickens [takiy-a(n)], Cats [mii], and Dogs [noqai]

\begin{tabular}{|c|c|c|c|}
\hline $\operatorname{MALE}\left(\jmath^{\Uparrow}\right)$ & FEMALE $(q)$ & NEUTER & WILD \\
\hline $\begin{array}{l}\text { male ass }=a j i r \gamma- \\
a(n) \text { eljige }(n) \\
\text { reindeer }=c a \text { bu } \gamma a\end{array}$ & & $\begin{array}{l}\text { gelded reindeer }= \\
\text { zaar'; zair (Khalkha) }\end{array}$ & wild ass $=$ qulan \\
\hline $\begin{array}{l}\text { boar }=\text { ajir } \gamma-a(n) \\
\text { yaqai, er-e yaqai }\end{array}$ & sow $=$ em-e raqai & 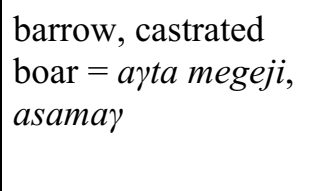 & $\begin{array}{l}\text { wild boar }= \\
\text { bodung, bodung } \\
\text { raqai, jerlig } \\
\text { raqai, qabang }\end{array}$ \\
\hline $\begin{array}{l}\text { cock, rooster }=a j i- \\
r \gamma-a(n) \text { takiy- } a(n), \\
\text { er-e takiy-a(n)} \\
\text { male dog }=e r-e \\
n o q a i \\
\text { cat }=\text { mii }[\text { Khalkha }]\end{array}$ & $\begin{array}{l}\text { hen = em-e takiy-a(n) } \\
\text { laying hen = öndög- } \\
\text { lögch (Khalkha) } \\
\text { bitch = ölücin noqai }\end{array}$ & & \\
\hline
\end{tabular}




\begin{tabular}{|c|c|}
\hline \multicolumn{2}{|r|}{ BY AGE } \\
\hline young & 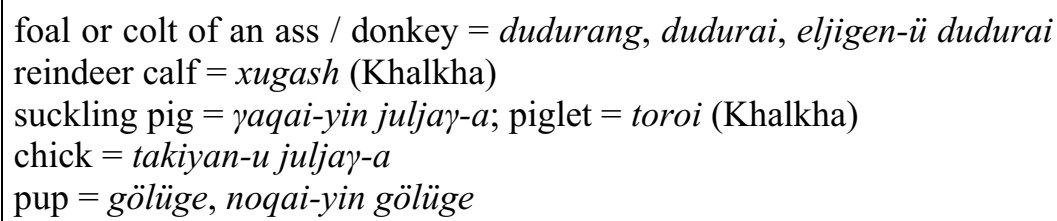 \\
\hline 2 years & 2-year-old boar $(\widehat{(})=$ qobusu(n) \\
\hline 3 years & 3-year-old boar $(\widehat{\jmath})$, pig = šobšuur (Oirat) \\
\hline 4 years & male reindeer in 4 th year $=x u u d a i($ Khalkha $)$ \\
\hline old & strong old boar $(\overbrace{}^{\Uparrow})=$ noytumal \\
\hline
\end{tabular}

Besides the traditional "five animals" there are some other domesticated animals that have been or are now important in Mongolian regions. These have been summarised following the same general pattern as for the five main animals. These animals, with the exception of the $\operatorname{dog}{ }^{29}$ have been rather neglected by scholars.

Charts 1-7 have been inserted to provide a basic guide to livestock classification. When used by Mongolians in their everyday life beyond animal husbandry itself, the impact of such a classification system becomes apparent. For this I have chosen to further develop three main areas which use domestic livestock classification: religion, law, and the social milieu. Often these areas overlap, especially in terms of law. Examples have been selected to show the range of influence and the defining role played by domestic livestock to carry out or satisfy the concerns which arise in everyday life.

The spiritual role surrounding domestic livestock has assumed two major aspects. The first involved the protection of the herds from natural calamities and disease, thus, assuring their increase. Various deities oversaw the well-being of the herds ${ }^{30}$ ritual invocations, blessings, charms, libations, anointings were performed directly on behalf of the animals. ${ }^{31}$ The second aspect made use of animal sacrifice to spiritually benefit man. Even today among the Buriat Mongols, for example, at midsummer and again in the autumn when herds are driven from pastures back to the villages, rites are performed by a shaman to ensure the increase of the herds. ${ }^{32}$ Some shamans have the "status" or "right" to select the sacrificial animal and perform the rite, including the incantations, the killing of the animal, its dismemberment, and proper disposal or distribution. ${ }^{33}$ There are examples of such "handling of the ram (or

\footnotetext{
${ }^{29}$ For comparative Turkic materials, see Tryjarski (1979) and Golden (1991).

${ }^{30}$ For a general overview of this see Heissig (1980), especially on folk religion.

${ }^{31}$ Material may be found on various rituals in Heissig (1968); Chabros (1992), Heissig Bawden (1971).

${ }^{32}$ Zhukovskaya (1997), p. 100.

${ }^{33}$ Zhukovskaya (1997), pp. 101-102, p. 107.
} 
8. Classification of Domestic Livestock as Used in Various Spheres of Nomadic Life:

A. Religion

\begin{tabular}{|c|c|c|c|}
\hline $\begin{array}{l}\text { Buddhist } \\
\text { (general) }\end{array}$ & \multicolumn{3}{|c|}{$\begin{array}{l}\text { living beings }=\text { amitan } \\
\text { the animal world = aduүusun-u oran }\end{array}$} \\
\hline $\begin{array}{l}\text { Folk Religion, } \\
\text { Shamanism }\end{array}$ & \multicolumn{3}{|c|}{ 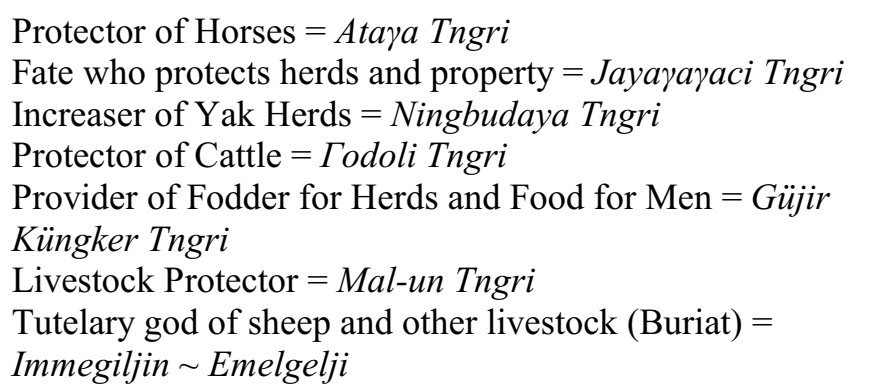 } \\
\hline Invocations & \multicolumn{3}{|c|}{ 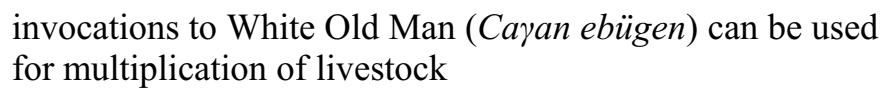 } \\
\hline $\begin{array}{l}\text { Libations } \\
\text { and Blessings } \\
\text { Anointing }\end{array}$ & \multicolumn{3}{|c|}{ 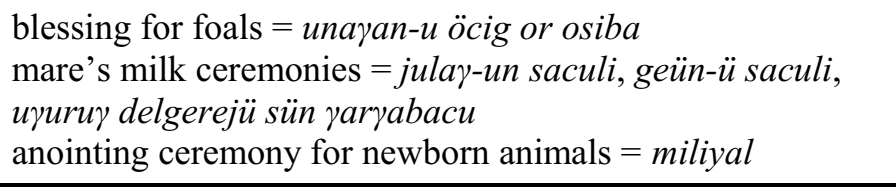 } \\
\hline $\begin{array}{l}\text { Consecration } \\
\text { Sacrifice }\end{array}$ & \multicolumn{3}{|c|}{ 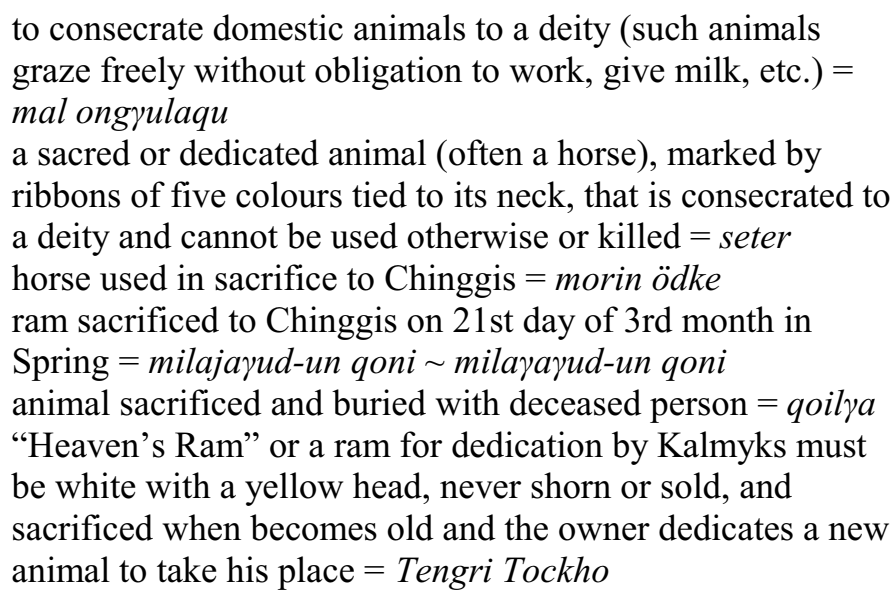 } \\
\hline \multicolumn{4}{|c|}{$\begin{array}{c}\text { Sacrificial Animals Determined by Muzzle }[q o s i \gamma u(n)] \text { Characteristics } \\
\text { offered in shamanistic practices to ancestral spirits }\end{array}$} \\
\hline \multicolumn{2}{|c|}{$\begin{array}{l}\text { Cold Muzzle = küiten qosizu-tu } \\
\text { (may not be used for sacrifice) }\end{array}$} & Neutral & 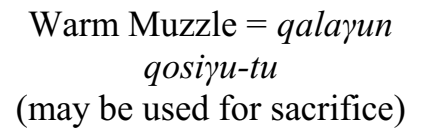 \\
\hline
\end{tabular}




\begin{tabular}{|c|c|c|}
\hline camels & sheep \\
goats & $\begin{array}{c}\text { cattle, yaks } \\
\text { (western } \\
\text { Mongolia) }\end{array}$ & $\begin{array}{c}\text { (Khalkha Mongols considered } \\
\text { cattle and yaks "warm") }\end{array}$ \\
\hline $\begin{array}{c}\text { (Rintchen considered cattle and } \\
\text { yaks "cold") }\end{array}$ & & cols \\
\hline
\end{tabular}

sheep)" (khonin barila) that could be considered hereditary, following the maternal line of the shaman. ${ }^{34}$ The selection of a sacrificial animal depended directly on classification categories ranging from sex to characteristics determined by the animal's muzzle. ${ }^{35}$ Chart $8 \mathrm{~A}$ summarises some of the elements found in these two major aspects of domestic animals in various religious roles of traditional Mongolian society.

To the spiritual role played by livestock, one can also add legal functions as they affected the clergy or shamans in both a State capacity and among the populace. For example, the Mongol-Oirat Regulations of 1640 attempted to limit the influence of shamans; breaches to this policy resulted in fines assessed in livestock. Shamans who were asked to perform certain functions or rites brought the fine of 1 horse each to the shaman and to the individual who had made the request. If a shaman cast a spell on the house of a noble he was fined 5 horses; if the spell was on the house of a commoner, the fine was 2 horses. The killing of water fowl, sparrows, or dogs for ritual purposes also bought a fine of 1 horse. When clergy wanted to take 1 in 10 males from the family, relatives could redeem the men or boys by paying in livestock according to rank: 5 head of livestock for a prince, 3 head for a commoner. ${ }^{36}$

The legal position of domestic livestock was not limited to religious practice but also reflected the importance of these animals to the economic, military, political, and social security of Mongolian nomadic society. Domestic livestock figured in the customary and codified laws of Mongolian peoples in two broad categories: (1) laws in which animals were used to satisfy obligations in the form of contracts, taxation, property and family inheritance, and punishment, usually in the form of fines; and (2) laws in which the individual, family, clan or community had obligations to domestic livestock. $^{37}$

There was clearly a hierarchy which governed both the "five traditional animals" and those who tended the herds. This is clear from various expressions or sayings such as "the soldier is the worst of men, the goat is the worst of livestock" (xünii adag tsereg, malyn adag yamaa). ${ }^{38}$ Offences committed by a herdsman could be punished by "demoting" him from caring for one type of animal to another. Thus, for example, in Chakhar a drunken cattle herder (ükercin) was sent to tend sheep

\footnotetext{
${ }^{34}$ Zhukovskaya (1997), p. 102.

${ }^{35}$ For details on muzzle characteristics, see Rintchen (1977) and Chabros (1992), p. 42, p. 102.

${ }^{36}$ Riasanovsky (1965), pp. 92-93.

${ }^{37}$ I have dealt with this topic of obligations to domestic livestock in a paper entitled "Law and Domestic Animals in Inner Asia" to be published in the proceedings of the 40th PIAC (Provo, Utah) which is forthcoming.

${ }^{38}$ Bawden (1997), p. 6.
} 
(qoninci) as a punishment for his inebriation. ${ }^{39}$ More well known, however, was the elaborate system of legal fines assessed in livestock as just due for a criminal or civil offence.

To illustrate the legal role of livestock, Chart 8B presents the types of fines, restitution or compensation, and rates of fines in use over the centuries and all expressed in livestock that had become a kind of currency used by nomadic peoples. ${ }^{40}$

\section{B. Law: Fines Assessed in Livestock}

\begin{tabular}{|c|c|}
\hline \multicolumn{2}{|r|}{ Types of Fines in Livestock } \\
\hline Mongolian Term & Definition in Terms of Legal Fine in Livestock \\
\hline aldanggi (historical) & a unit of a fine; usually assessed for slight crimes \\
\hline anju (hist.) & $\begin{array}{l}\text { a unit of a fine; usually assessed for heavy crimes, e.g. } \\
\text { murder, bodily injury/assault, theft of livestock }\end{array}$ \\
\hline$b a \gamma-a$ & $\begin{array}{l}\text { a fine for crime(s) against the order of the Qosizun(s)/ } \\
\text { Banner(s) during the Ch'ing dynasty }(1644-1911) \text {, in } \\
\text { which the payment went directly to the Qosizun(s)/ } \\
\text { Banner(s) }\end{array}$ \\
\hline boda, bodu, bod & $\begin{array}{l}\text { a measure of livestock = "large livestock", i.e. horse, } \\
\text { camels, and cattle, used in assessing the rate of a fine. } \\
1 \text { bodu }=1 \text { horse or } 1 \text { cow, or } 7 \text { sheep, or } 14 \text { goats. } \\
\text { Camels were more valuable and }=1 \frac{1}{2}-2 \text { bodu. It would } \\
\text { seem from lexical sources that in more modern times the } \\
\text { value of sheep and goats necessary to equal } 1 \text { bodu was } \\
\text { reduced to } 5-7 \text { sheep or } 7-10 \text { goats }\end{array}$ \\
\hline$b o \gamma, b a \gamma-a$ & $\begin{array}{l}\text { a measure of livestock = "small livestock", i.e. sheep and } \\
\text { goats, which could be used in assessing the rate of a fine }\end{array}$ \\
\hline oro & $\begin{array}{l}\text { compensation for loss which may also be paid in } \\
\text { livestock and which may be assessed on top of the fine }\end{array}$ \\
\hline tabun, tabun mal & $\begin{array}{l}\text { "the five animals", i.e. horses, camels, cattle, sheep and } \\
\text { goats, but may be used in assessing a fine of livestock } \\
\text { known as "fives" in which the specific } 5 \text { animals are } \\
\text { named, often including age and sex. Usually a fixed rate } \\
\text { under any specific law code, the fine(s) were paid in one } \\
5 \text { or multiples of } 5\end{array}$ \\
\hline
\end{tabular}

${ }^{39}$ Pozdneyev, 1977 edition, I, pp. 430-431.

${ }^{40}$ Further details may be found in Bira (1977); Futaki (1981), Riasanovsky (1965). 


\begin{tabular}{|c|c|c|}
\hline tor-, torya- & \multicolumn{2}{|c|}{$\begin{array}{l}\text { used in a specialised sense, meaning to impose a fine in } \\
\text { livestock }\end{array}$} \\
\hline $\begin{array}{l}\therefore \text { yal-a-yin tabun- } i \\
\text { kemjiy-e(n), or yal-a- } \\
\text { yin yisün-i kemjiy- } \\
\text { e(n) }\end{array}$ & \multicolumn{2}{|c|}{$\begin{array}{l}\text { a fine; during the 16th-century Ch'ing dynasty, it was } \\
\text { assessed for crimes against individuals (as opposed to } \\
\text { the State or Banner) or groups and the payment was } \\
\text { given to those wronged; } \\
\text { hence }(\therefore) \text {, a more general usage, "a fine at the rate of } \\
5(\mathrm{~s}) \text { in livestock" or "a fine at the rate of } 9(\mathrm{~s}) \text { in live- } \\
\text { stock" respectively }\end{array}$} \\
\hline yisün mal & \multicolumn{2}{|c|}{$\begin{array}{l}\text { literally "9 animals", but used in the legal sense in } \\
\text { assessing a fine in livestock known as "nines" in which } \\
\text { the specific animals are named, often including age and } \\
\text { sex. Usually a fixed rate under any specific law code, the } \\
\text { fine(s) were paid in one } 9 \text { or multiples of } 9\end{array}$} \\
\hline \multicolumn{3}{|c|}{$\begin{array}{l}\text { Restitution/Compensation by Herdsmen for Horses that Died of Disease } \\
\text { in the Imperial Herds during the Yüan Period (Yüan shih 100) }\end{array}$} \\
\hline $\begin{array}{l}\text { Number of Dead } \\
\text { Horses }\end{array}$ & $\begin{array}{l}\text { Restitution/Compensation } \\
\text { Rate }\end{array}$ & Substitution Permissible \\
\hline $\begin{array}{l}1 \text { horse } \\
2 \text { horses } \\
3 \text { horses }\end{array}$ & $\begin{array}{l}1 \text { ewe } \\
1 \text { two-year-old horse } \\
1 \text { full grown mare }\end{array}$ & $\begin{array}{l}\text { the equivalent in sheep, } \\
\text { camels or cattle }\end{array}$ \\
\hline \multicolumn{3}{|c|}{ Examples of Rates of Fines in Livestock Under Various Legal Codes } \\
\hline Law Code & $\begin{array}{l}\text { Fine in } 5 \mathrm{~s}[y a l-a-y i n \\
\text { tabun-i kemjiy-e(n)] }\end{array}$ & $\begin{array}{l}\text { Fine in 9s }[\text { yal-a-yin yisün- } \\
\quad \text { i kemjiy-e(n)] }\end{array}$ \\
\hline $\begin{array}{l}\text { Altan Qayan's Code } \\
\text { (16th century) }\end{array}$ & $\begin{array}{l}1 \text { horse, } 1 \text { bullock, } \\
3 \text { sheep-goats }\end{array}$ & $\begin{array}{l}2 \text { horses, } 2 \text { bullocks, } \\
5 \text { sheep-goats }\end{array}$ \\
\hline $\begin{array}{l}\text { Mongol law book of } \\
\text { K'ang-hsi period } \\
(1662-1722)\end{array}$ & $\begin{array}{l}1 \text { ox, } 1 \text { cow, } 1 \text { three-year- } \\
\text { old bull, } 2 \text { calves }\end{array}$ & $\begin{array}{l}2 \text { horses, } 2 \text { oxen, } 2 \text { cows, } \\
2 \text { three-year-old bulls, } \\
1 \text { calf }\end{array}$ \\
\hline $\begin{array}{l}\text { Qalq-a jirum (1709; } \\
\text { subsequent regula- } \\
\text { tions through } 1770)\end{array}$ & $\begin{array}{l}1 \text { three-year-old horse, } \\
1 \text { three-year-old bullock, } \\
3 \text { two-year-old sheep }\end{array}$ & $\begin{array}{l}2 \text { horses, } 2 \text { oxen, } 2 \text { cows, } \\
2 \text { sheep, } \\
1 \text { two-year-old calf }\end{array}$ \\
\hline Regulations of 1789 & & $\begin{array}{l}2 \text { horses, } 2 \text { oxen, } 2 \text { cows, } \\
2 \text { three-year-old bulls, } \\
1 \text { two-year-old calf }\end{array}$ \\
\hline
\end{tabular}




\begin{tabular}{|l|l|l|}
\hline Code of 1815 & $\begin{array}{l}2 \text { horses, } 2 \text { oxen, } 2 \text { cows, } \\
2 \text { three-year-old bullocks, } \\
1 \text { two-year-old bullock }\end{array}$ \\
\hline
\end{tabular}

Livestock classification also played a major role in establishing and maintaining social norms in Mongolian society. Even breaches of etiquette could result in fines calculated in livestock. Failure to offer kumiss, for example brought a fine of 1 sheep; or denying lodging for the night brought a heavy fine - 1 three-yearold mare, i.e. an animal entering prime breeding years. For desecrating a tomb (opening) of a distinguished person, a fine of $1 \times 9$ livestock was levied, or 5 livestock for an undistinguished person. The cutting off of a horse's tail or ear also brought a fine of $1 \times 9$ livestock. The individual who failed to extinguish a campfire was fined 1 horse. ${ }^{41}$ From the gifts one presented to social contracts arranging marriage, divorce and adoption, such obligations were often fulfilled with livestock, carefully agreed upon between the parties. ${ }^{42}$ Betrothal, marriage, adoption, divorce including redemption rights, and widow remarriage were always very complex affairs based on the rank of the parties involved. Infractions in marriage relations - elopement, seduction, adultery, rape - were settled in livestock in later years, mitigated from harsher penalties in the times of Chinggis when, for example, adulterers received a death sentence. Chart $8 \mathrm{C}$ which follows reflects some of these social functions fulfilled in part by domestic livestock.

C. The Social Milieu

\begin{tabular}{|c|c|}
\hline \multicolumn{2}{|c|}{ 1. Livestock as Gift or Tribute } \\
\hline $\begin{array}{l}\text { tribute consisting of } 9 \text { white animals, i.e. } \\
1 \text { camel and } 8 \text { horses }\end{array}$ & 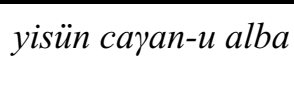 \\
\hline $\begin{array}{l}\text { to offer a riding horse as a gift; in early times } \\
\text { this could be between sworn brothers (anda), } \\
\text { but later on extended to relatives, especially } \\
\text { children }\end{array}$ & unuүul- \\
\hline \multicolumn{2}{|c|}{ 2. Livestock for Marriage and Divorce } \\
\hline $\begin{array}{l}\text { animals or dowry livestock given on entering a } \\
\text { marriage contract }\end{array}$ & boyulaqu mal \\
\hline
\end{tabular}

${ }^{41}$ Riasanovsky (1965), p. 97, p. 105 , p. 123 , p. 124 , p. 125.

${ }^{42}$ Besides Riasanovsky (1965), especially useful in compiling the chart which follows is Miyawaki-Okada's forthcoming article. 


\begin{tabular}{|c|c|}
\hline $\begin{array}{l}\text { dowry livestock over which the bride had } \\
\text { certain rights as opposed to the dowry (sitkül) } \\
\text { given by the bride's parents to the groom's } \\
\text { parents and over which the bride had no rights }\end{array}$ & inje $\sim$ ingje $\sim$ ingje mal \\
\hline $\begin{array}{l}\text { ransom livestock, but also used to mean } \\
\text { livestock returned to the wife's family after a } \\
\text { divorce; a rejected wife (ekener-iyen yoluqu) } \\
\text { could be redeemed by relatives, usually } \\
\text { according to rank }\end{array}$ & joliy mal \\
\hline $\begin{array}{l}\text { a share or portion of an inheritance; a gift of } \\
\text { livestock in the 3rd year of a marriage by the } \\
\text { bride's family directly to their son-in-law; } \\
\text { sometimes it was considered as a gift in the 3rd } \\
\text { year of marriage to prevent a divorce }\end{array}$ & $\ddot{o m} c i q u b i$ \\
\hline \multicolumn{2}{|c|}{$\begin{array}{l}\text { Marriage Gifts of Pregnant Livestock } \\
\text { Determined by Season, Statute of } 1709\end{array}$} \\
\hline Type of Livestock & $\begin{array}{l}\text { Season When Pregnancy Can } \\
\text { Be Verified }\end{array}$ \\
\hline she-camel & last month of summer \\
\hline mare & last month of winter \\
\hline cow & last month of autumn \\
\hline ewe & middle month of autumn \\
\hline \multicolumn{2}{|c|}{ Infractions of Betrothal or Marriage Arrangements } \\
\hline seducing another's wife (consensual) & $\begin{array}{l}\text { husband had right to seize } \\
\text { wife and all of seducer's } \\
\text { livestock }\end{array}$ \\
\hline $\begin{array}{l}\text { elopement with a betrothed girl: } \\
\text { 1. for a noble } \\
\text { 2. for a middle class person } \\
\text { 3. for a lower class person }\end{array}$ & $\begin{array}{l}\text { fine in livestock: } \\
\text { 1. } 7 \text { head of livestock } \\
\text { 2. } 5 \text { head of livestock } \\
\text { 3. } 1 \text { camel }\end{array}$ \\
\hline $\begin{array}{l}\text { adultery: } \\
\text { 1. with wife of a prince } \\
\text { 2. ordinary adultery (i.e. with commoner) }\end{array}$ & $\begin{array}{l}\text { fine in livestock: } \\
\text { 1. a goat and its kid } \\
\text { 2. a 4-year-old horse to the } \\
\text { wrong husband and a } 3 \text {-year- } \\
\text { old horse to the judge }\end{array}$ \\
\hline
\end{tabular}




\begin{tabular}{|l|l|}
\hline crime of rape: & fine in livestock: \\
1. of a married woman & $1.1 \times 9$ of livestock \\
2. of a maiden & $2.2 \times 9$ of livestock \\
3. of a slave & 3.1 horse \\
\hline
\end{tabular}

The observation of nature and attempts to classify it are features of civilisation. Noted early on by the Greek philosopher Democritus of Abdera (c. 460-370 BC), the defining of one's world is characteristic of all civilisations. In the early stages of such classification, the diversity of life enlarges knowledge. When carried to extremes or an obsession, such classification can create a jargon, which may separate one from the group and hence from mutual understanding; at its worst, it can be used to challenge a positive emphasis on diversity, changing it into adversity and subsequent strife. Practiced by the nomadic steppe peoples of Central Eurasia, organising such thought into categories was also similar to that of most societies in the world, leading to a richness in vocabulary and understanding of the natural world by direct observation, a key element in developing scientific thought. ${ }^{43}$ For Mongolians such classification of livestock also assumed a very practical integration into the everyday life.

\section{References}

Amguleng (1990): Horses and Cattle Atlas with Their Local Names. Jirem League and Beijing. Illustrated (color) with text in English, Chinese and Mongolian (vertical script).

Balsan, D. (1986): Xülgiin sainyg unaya gevel..., Ulaanbaatar, BNMAU Ardyn bolobsrolyn yaamny surax bicig, setgüüliin negdsen redaktsyn gazar.

Batsukh, G. - Zagdsuren, E. (1991): Sheep Breeds of Mongolia. World Animal Review 68, 3, pp. 11-25.

Bawden, Charles R. (1988): Some Aspects of the Development of a Modern Mongolian Terminology. Ural-Altaische Jahrbücher n.s. 8, pp.164-179.

Bawden, Charles R. (1997): Mongolian-English Dictionary. London, Kegan Paul International.

Bazin, Louis (1967): Noms de la 'chèvre' en turc et en mongol. Studia Altaica. Festschrift für Nikolas Poppe zum 60. Geburtstag, pp. 28-32; reprinted in Bazin's Les Turcs, des mots, des hommes. Budapest, Akadémiai Kiadó, 1994, pp. 265-270.

Bazin, Louis (1970): Les noms du 'yak' chez les peuples turcs et mongols. In: Beiträge zur Alten Geschichte und deren Nachleben. II., edited by R. Stiehl and H. E. Stier, pp. 213-221; reprinted in Bazin's Les Turcs, des mots, des hommes. Budapest, Akadémiai Kiadó, 1994, pp. 271-277.

Bira, Š. (1977): A Sixteenth Century Mongol Code, translated by Rashidonduk and V. Veit. Zentralasiatische Studien 11, pp. 7-34. [For the original: XVI zuuny negen Mongol tsaasny bicig. Sinjlex Uxaany Akademiin Medee 3 (1975), pp. 34-54.]

Bodde, Derk (1939): Types of Chinese Categorical Thinking. Journal of the American Oriental Society 59 , pp. 200-219.

${ }^{43}$ For a broader discussion of this see Meserve (1996). 
Bosson, James (1993): The Heritage of Mongol Pastoral Nomadism. In: International Symposium on Mongolian Culture, Taipei, pp. 475-483.

Chabros, Krystyna (1992): Beckoning Fortune: A Study of the Mongol dalalya Ritual. Wiesbaden, Otto Harrassowitz.

Cirtautas, I. (1965): Die Lieblingspferdefarben der Türken. Central Asiatic Journal 10, pp. 157-160.

Coloo, Ž. (1976): Notes on Mongol Uriankhai Vocabulary. AOH 30, pp. 59-67.

Cowen, Jill Sanchia (1989): Kalila wa Dimna: An Animal Allegory of the Mongol Court. The Istanbul University Album. New York, Oxford University Press.

Futaki, Hiroshi (1981): A Study of the Newly Discovered Juridical Documents of KhalkhaMongolia. Ajia Afurika gengo bunka kenkyu [Journal of Asian and African Studies, Tokyo] 21, pp. 49-73. In Japanese with an English summary, pp. 49-50.

Golden, P. B. (1991): The Dogs of the Medieval Qïpčaqs. In: Varia Eurasiatica. Festschrift für Professor András Róna-Tas (Szeged, Department of Altaic Studies), pp. 45-55.

Hasbagan - Chen Shan (1996): The Cultural Importance of Animals in Traditional Mongolian Plant Nomenclature. In: Culture and Environment in Inner Asia, 2. Society and Culture, edited by Caroline Humphrey and David Sneath, Cambridge, The White Horse Press, pp. 25-29.

Heissig, Walther (1968): Zwölf Zeremonialtexte zur Stutenaussonderung aus Qanggin (Ordus). Zentralasiatische Studien 2, pp. 265-306.

Heissig, Walther, assisted by Charles Bawden (1971): Catalogue of Mongol Books, Manuscripts and Xylographs. Copenhagen, The Royal Library.

Heissig, Walther (1980): The Religions of Mongolia. London, Routledge \& Kegan Paul.

Hillenbrand, Robert (1990): Mamlūk and Īlkhānid Bestiaries: Convention and Experiment. Ars Orientalis 20, pp. 149-187.

Howorth, Sir Henry (1927): History of the Mongols from the 9th to the 19th Century. Part IV: Supplement and Indices. London, Longmans, Green, and Co.

Ishnyam, Ts. - Maidar, I. (1988): Temeenii anatomiin öngöt atlas / Atlas anatomii verblyuda. Ulaanbaatar, Ulsyn Xevleliin Gazar.

Jagchid, Sechin - Hyer, Paul (1979): Mongolia's Culture and Society. Boulder, Westview Press.

Jambaldorj, S. (1996): Morin erdene. Ulaanbaatar.

Jambaldorj, S. (1997): Temee tengeriin amitan. Ulaanbaatar.

Jardine, N. - Secord, J. A. - Spary, E. C. (eds) (1996): Cultures of Natural History. Cambridge, Cambridge University Press.

Krueger, John R. (1963): Toward Greater Utilization of the Ch'ien-lung Pentaglot: The Mongolian Index. Ural-Altaische Jahrbücher 35, pp. 228-240.

Larson, Frans August (1930): Larson, Duke of Mongolia. Boston, Little, Brown, and Company.

Lubsangjab, Choi. (1974): Customary Ways of Measuring Time and Time Periods in Mongolia. Journal of the Anglo-Mongolian Society 1.1, pp. 8-16.

Mayrhofer, Manfred (1960): Mongolische Pferdewörter bei einem Sanskrit-Lexikographen? Paideuma. Mitteilungen zur Kulturkunde Bd. 7, Heft 4/6, pp. 96-98.

Meserve, Ruth I. (1996): On Medieval and Early Modern Science and Technology in Central Eurasia. In: Toronto Studies in Central and Inner Asia No. 2: Cultural Contact, History and Ethnicity in Inner Asia, edited by Michael Gervers and Wayne Schlepp. Toronto, Joint Centre for Asia Pacific Studies, pp. 49-70.

Meserve, Ruth I.: Law and Domestic Animals in Inner Asia. In: Proceedings of the 40th PIAC, Provo, Utah. Forthcoming.

Miyawaki-Okada, Junko: Women's Property in the History of Nomadic Societies. In: Proceedings of the 40th PIAC, Provo, Utah. Forthcoming. 
Pelliot, Paul (1931): Les Formes turques et mongoles dans la nomenclature zoologique du Nuzhatu'l-kulüb. Bulletin of the School of Oriental Studies 6, pp. 555-580.

Poppe, Nikolaus (1962): Pferdenamen in der Geschichte und Sage der Nomaden Zentralasiens. Oriens Extremus 9, pp. 97-104.

Poppe, Nicholas (1964): On Some Mongolian Names of Wild Beasts. Central Asiatic Journal 9, pp. 161-174.

Poppe, Nicholas (1977): The Use of Colour Names in Mongolian. The Canada-Mongolia Review 3.3, pp. 118-134.

Pozdneyev, A, M. (1977): Mongolia and the Mongols, I-II. translated by William H. Dougherty, Uralic and Altaic Series, Volumes 61/1-2. Bloomington, Indiana University.

Qiu, Huai - Ju Zhiyong - Chang Zhijie (1993): A Survey of Cattle Production in China. World Animal Review 76.3, pp. 12-18.

Riasanovsky, Valentin A. (1965): Fundamental Principles of Mongol Law. Uralic and Altaic Series, Volume 43. Bloomington, Indiana University Publications. The Hague, Mouton \& Co.

Rintchen, Yöngsiyebü (1977): Pourquoi on offre des chevaux et des moutons aux esprits chamaniques mongols. L'Ethnographie, Numéro Spécial: Voyages Chamaniques, No. 74-75, pp. 155-156.

Ritvo, Harriet (1997): The Platypus and the Mermaid and Other Figments of the Classifying Imagination. Cambridge, Harvard University Press.

Ross, I. Clunies (1936): A Survey of the Sheep and Wool Industry in North-Eastern Asia. With Special Reference to Manchukuo, Korea, and Japan. Commonwealth of Australia, Council for Scientific and Industrial Research, Pamphlet No. 65, Melbourne.

Sárközi, Alice (1976): A Mongolian Manual of Divination by Means of Characteristics of the Land. In: Tractata Altaica, edited by Walther Heissig, John R. Krueger, Felix J. Oinas, and Edmond Schütz. Wiesbaden, Otto Harrassowitz, pp. 583-604.

Schmidt, Hans-Peter (1980): Ancient Iranian Animal Classification. Studien zur Indologie und Iranistik 5/6, pp. 209-244.

Schubert, Johannes (1971): Paralipomene Mongolia: Wissenschaftliche Notizen über Land, Leute in Lebensweise in der Mongolischen Volksrepublik. Veröffentlichungen des Museums für Völkerkunde zu Leipzig, Heft 19. Berlin, Akademie Verlag.

Sinor, Denis (1962): Some Altaic Names for Bovines. AOH 15, pp. 315-324.

Sinor, Denis (1965): Notes on the Equine Terminology of the Altaic Peoples. Central Asiatic Journal 10, pp. 307-315.

Smith, Brian K. (1994): Classifying the Universe: The Ancient Indian Varna System and the Origins of Caste. New York, Oxford University Press.

Tryjarski, Edward (1979): The Dog in the Turkic Area: An Ethnolinguistic Study. Central Asiatic Journal 23, pp. 297-319.

Uray-Kőhalmi, Käte (1959): Zwei Systeme der Altersbezeichnungen des Viehes bei den Mongolen. Studia Mongolica (Ulaanbaatar) 1.31, pp. 3-10 (with a Mongolian summary, p. 10); the same article appeared in Studia Mongolica 2.9 (1961), pp. 130-135 (complete Mongolian text), pp. 136-142 (complete German text). [Reprinted in 1961.]

Uray-Kőhalmi, K. (1966): Die Farbbezeichnungen der Pferde in den mandschu-tungusischen Sprachen. $A O H 19$, pp. 45-55.

Weiers, Michael (1969), Untersuchungen zu einer historischen Grammatik des präklassischen Schriftmongolisch. Asiatische Forschungen, Bd. 28. Wiesbaden, Otto Harrassowitz.

Wu-t'i Ch'ing-wen chien, Peking, 1957.

Yeo, Richard (1991): Reading Encyclopedias: Science and the Organization of Knowledge in British Dictionaries of Arts and Sciences, 1730-1850. Isis 82, pp. 24-49. 
Yüce, Nuri (1991): Tiere in türkischen Sprichwörtern. In: Altaica Osloensia, edited by Bernt Brendemoen. Oslo, Universitetsforlaget, pp. 391-400.

Zhukovskaya, N. L. (1997): The Shaman in the Context of Rural History and Mythology (Tory Village, Tunka District, Buryat Republic). Inner Asia: Occasional Papers (Cambridge) 2.1, pp. 90-107. 